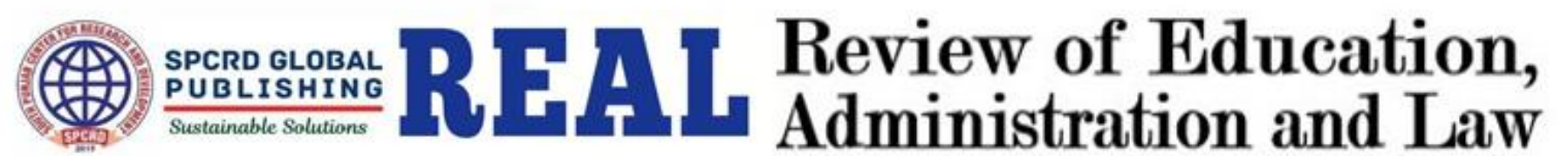 \\ Journal homepage: http://real.spcrd.org ISSN (Print): 2708-1788 ISSN(Online): 2708-3667
}

\section{Factors Affecting the Socio-Economic Status of Households in Southern Punjab}

\author{
a Salyha Zulfiqar Ali Shah, ${ }^{b}$ Imran Sharif Chaudhry, ${ }^{c}$ Fatima Farooq \\ ${ }^{a}$ Assistant Professor, School of Economics, Bahauddin Zakariya University Multan, Pakistan \\ Email: salyhazulfiqar@bzu.edu.pk \\ ${ }^{\mathrm{b}}$ Director, School of Economics, Bahauddin Zakariya University Multan, Pakistan \\ Email: imran@bzu.edu.pk \\ ${ }^{c}$ Assistant Professor, School of Economics, Bahauddin Zakariya University Multan, Pakistan
}

\begin{tabular}{ll}
\hline ARTICLE DETAILS & ABSTRACT \\
\hline History: & The Households having low socio-economic status possess less resource \\
Accepted 12 Sep 2020 & in term of wealth and income to resist against any kind of external \\
Available Online 30 Sep 2020 & shocks. Apart from heath shocks (physical and mental disabilities) there \\
& are numerous other factors that force them to follow subsistence life \\
& style having low per capita income. A primary level data has been \\
Keywords: & collected to examine the socio economic status of households in Southern \\
Per Capita Income; Economic & Punjab for the year 2019.The findings show that household size, \\
Development; Socio-economic & occupation, dependency ratio, mental disability and physical disability \\
Status; Household; OLS & are negatively affecting economic development across the region. \\
Regression Technique; Southern & However, age, education of the household head, own house, spouse 's \\
Punjab; Pakistan & participation, remittances, number of earners in the household and value \\
& of physical assets are increasing economic development in Southern \\
JEL Classification: & Punjab. Developing strategies, adequate planning and their timely \\
C31, F63, I25, O12, I15 & implementation is very crucial for the government to pursue the process \\
& of economic growth and development of the poor countries like Pakistan.
\end{tabular}

DOI: $10.47067 /$ real.v3i2.69

(C) 2020 The authors. Published by SPCRD Global Publishing. This is an open access article under the Creative Commons AttributionNonCommercial 4.0

Corresponding author's email address: imran@bzu.edu.pk

\section{Introduction}

Economic development helps to identify the fundamental causes of underdevelopment and to generate policies that basically accelerate the per capita income of the poor nations. The most imperative and vital aim of the underdeveloped countries is rapid economic growth and development. Better macroeconomic performance, high income level, creating human capital, employment opportunities, high exports, provision of socio economic needs and poverty mitigation, improved standard of living of the people are the key factors that are generally associated with the economic growth and development. Hence the overall concept of economic development adheres to the agenda, aiming to improve the well-being of the people. The present study focuses on Southern Punjab, which 
comprises of 3 divisions. It is a mainly a developing and backward region of the Punjab. It constitutes mostly on small cities, vast rural and desert areas. Considering the problem of rising poverty in in Southern Punjab, have been focused to analyze the factors affecting socio- economic status of households in Southern Punjab. These divisions have received very little prosperity both at the policy and empirical level.

Keeping in view the above discussion, this papers is structured as follows. The section 2, discusses the review of literature. The section 3 presents the data and methodology. The section 4 provides the empirical findings. The section 5 offers the concluding remarks.

\section{The Literature Review}

Various strands of literature are found on poverty. Moreover, it is generally considered as a plague and extremely serious matter to ponder across the world.

Romer (1986), presented his findings that showed positive, long-run economic growth rates can be achieved through technological progress, learning by doing and knowledge spillover. Lucas (1988) studied the mechanics of economic development and realized the importance of physical and human capital. The study contended the importance of learning by doing, and training on the job comprises of human capital. Countries which are naturally endowed with resources achieve economic growth through comparative advantage more quickly as compare to the economies which are initially poor. Majority of east Asian countries have progressed on the basis of trade, so trade led growth are only because of an increase in exports resulting a sustained income level

Barro and Lee (1994) examined the determinants of economic growth for different countries. The author has collected secondary data of 95 different countries to study the growth rates over the two decades using regression analysis. The study has revealed that There was positive relative relation between gross investment and growth rates but this relation was not much strongly related to each other. Political instability is harmful for growth but public investment on education enrollment, schooling of children and heath can play a positive role in presenting improved growth rates. Hall and Jones (1999) and Rodrick (1999) found the positive relation between economic development and property rights.

Croppenstedt (2006) studied the factors affecting household income in rural areas of Egypt. The author has collected data from household survey data during the year 1997 To analyzes household income structure and determinants. The results have found that large households have less per capita income. Female headed households obtain a much smaller proportion of their income from wage employment as well as from household enterprise activity. It was also observed that young household heads are earning more income from wage employment having higher per-capita income as compare to older household heads. Earning of male and female labor are the same in agriculture sector but greater in case of male household head if working in formal sector. A longer-term planning on employment generation through increased access to education for men and women is required.

Smith (2007) examined the economic status of the household in the Soviet Union. The author has collected data from the three Baltic republics, Moscow and the Belarus regions to analyze the factors affecting the household income. The results showed that the percentage of people over 60 and that is mostly retired people in the sample are relatively small. This indicates that older workers and pensioners are less likely to be the primary income earners of their households. The results conclude that a high income household is usually middle-aged, well-educated, married male having good health 
is the primary earner of the household. People living in a huge town or cities have a significant positive role in contributing in the regional income distribution.

Mirvis and Clay (2008) explained the importance of health as a source of economic growth in the Mississippi Delta, America. The study has concluded that health and economic issues are same and identical across the countries many other barriers related to health and non-health issue must be addressed to rectify the health conditions of the region. Employment opportunities must be generated for the people and proper utilization of resources are necessary for the community. The study further suggested that long term strategies along with the collaboration with academic institutions and researchers were required to reduce health disparities. It was further stated that there is no development without better health conditions of the economy.

Leyaro and Morrissey (2010) analyzed the determinants of household income in Tanzania. the author has collected data from the Tanzania Household Budget Survey during the years 1991/92, 2000/01 and 2007. The authors have analyzed many demographic and other variables to show association with household income. The finding has revealed that large household's size has less income. Household living in urban areas are likely to have higher income as compare to the household living in rural areas. Household living in the Coastal zone, have more income level around 15\% more as compare to the poorest region. The results showed positive correlation between years of education of the household head with higher income. Average incomes of agriculture households are lower than for manufacturing households.

Aikaeli (2011) studied the income status of households in Tanzania. The author has collected data from 1610 household, 150 communities and 1239 enterprises from seven different regions. The dependent variable was per capita income in the study. The study has concluded that education is significant and showing positive relation with the per capita income. This shows that higher the education level of the household head more will be the per capita income. Educated Households having associated with farming activities are more likely to have higher per capita income as compare to less educated household. Increase in the number of workers and land as an asset, rural non-farm activities played a vital role in raising the per capita income of the household. those household headed by female have per capita income as compare to the household headed by the male.

Tuyen (2015) studied the socio economic determinants of household in Vietnam. The authors have collected secondary data focused on the household of the ethnic minorities, using different multiple regression models. The dependent variable was per capita income. The study has revealed that mostly the household is associated with the agriculture activities. However, there is a significant and positive role of education, holding of fixed assets and non-farm employment opportunities in raising the income of the household.

A panel cross country data was collected by Vedia-Jerez and Chasco (2016) to examined the long run determinants of economic growth in South America during the year 1960-1980 and from1981-2008 using GMM estimator. The study involved two econometric model including GDP per capita and Foreign direct investment were taken as dependent variable respectively. Different institutional (quality, security of contract and property rights), Institutional constraints, macro shocks, human capital and other variable are taken as independent variables. The study concluded that for long term economic growth, human and physical capitals are necessary. Foreign direct investment (FDI) accompanied with secondary education accelerate management skills and technology. Macroeconomic disturbances reduce the pace of FDI and economic growth. 
It has been found out from past studies that developing countries are suffering from various socio economic issues. The denial of employment opportunities, low infrastructure, lack of education and physical assets and limited access to market have forced poor countries to remain deprived and underdeveloped. This study presents an analysis of variables that are closely linked with the socioeconomic status of the household. The next section will present the data and methodology.

\section{Data and Methodology}

The primary data has been collected through a field survey from the respondents i.e. the household head, comprising of three divisions for the year 2019 in Southern Punjab. The study consists of 1068 observations, adopted simple random and stratified sampling.

\subsection{Descriptive Analysis}

Descriptive statistics that explains a given data set, which can be either a picture of the complete or a sample of a population.

\subsection{Correlation Matrix}

$$
\text { Mean }=\begin{gathered}
\sum \mathrm{X} \\
---- \\
\mathbf{N}
\end{gathered}
$$

A correlation matrix is used as an input into a more advanced analysis, a path to review data and helpful for investigating advanced analyses.

$$
\text { Correlation }=\frac{\sum X Y-\frac{\left(\sum X\right)\left(\sum Y\right)}{n}}{\sqrt{\left[\sum X^{2}-\frac{\left(\sum X\right)^{2}}{n_{x}}\right]\left[\sum Y^{2}-\frac{\left(\sum Y\right)^{2}}{n_{y}}\right]}}
$$

\subsection{Regression Model}

The study used a binomial logistic regression having dependent variable of dichotomous nature. The logistic regression model can be explained through the equation:

$$
\mathrm{Y}^{*}=\beta_{1}+\beta_{2} \mathrm{X} 2 \mathrm{i}+\beta_{3} \mathrm{X} 3 \mathrm{i}+\ldots \ldots \ldots \ldots \ldots \ldots \ldots+\beta_{\mathrm{k}} \mathrm{X}_{\mathrm{ki}}+\epsilon_{\mathrm{i}}
$$

$\mathrm{Y}^{*}$ is the dependent variable representing the per capita income of the household and Xs are the various socioeconomic and demographic indicators that determine the economic development at the household level in Southern Punjab. 
Table 1: Variables Utilized for OLS Regression Estimates

\begin{tabular}{|c|c|c|}
\hline Variables & \multicolumn{2}{|c|}{ Description of the Variables } \\
\hline \multicolumn{3}{|c|}{ Dependent Variable } \\
\hline LNPCI & $\begin{array}{l}\text { Log of Per Capita } \\
\text { Income }\end{array}$ & $\begin{array}{l}\text { It is the proxy for Economic Development. It is the natural log } \\
\text { of per capita income }\end{array}$ \\
\hline \multicolumn{3}{|c|}{ Independent Variables } \\
\hline \multicolumn{3}{|c|}{ Demographic Variables } \\
\hline HAGE & $\begin{array}{l}\text { Age of Household } \\
\text { head }\end{array}$ & Complete years of respondent 's age \\
\hline HSIZE & Household ‘s Size & The total person in a household \\
\hline DR & Dependency Ratio & Total dependents divided by total household size. \\
\hline \multicolumn{3}{|c|}{ Economic Variables } \\
\hline OCC & $\begin{array}{ll}\text { Occupation } & \text { of } \\
\text { Household Head } & \\
\end{array}$ & $\begin{array}{l}=1 \text { if household head working in primary sector } \\
=0 \text { if household head not working in primary sector }\end{array}$ \\
\hline NOEIH & Number of Earners & The household comprising of total earners \\
\hline LNVOLPA & Physical Assets & $\begin{array}{l}\text { The natural log of value of physical assets own by the } \\
\text { household }\end{array}$ \\
\hline $\mathrm{OH}$ & Own House & $\begin{array}{l}=1 \text { if household has own house } \\
=\mathrm{O} \text { if household not own house }\end{array}$ \\
\hline REM & Remittances & $\begin{array}{l}=1 \text { if household receive remittances } \\
=0 \text { if household not receive remittances }\end{array}$ \\
\hline SP & Spouse's Participation & $\begin{array}{l}=1 \text { if the Spouse participate in labor force } \\
=0 \text { if the Spouse not participate in labor force }\end{array}$ \\
\hline CRD & Access to Credit & $\begin{array}{l}=1 \text { if household have an access to credit } \\
=\mathrm{O} \text { if household have not access to credit }\end{array}$ \\
\hline \multicolumn{3}{|c|}{ Social variables } \\
\hline MI & Mental Disease & $\begin{array}{l}=1 \text { if a person in a family is mentally ill } \\
=\mathrm{O} \text { if a person in a family is not mentally ill }\end{array}$ \\
\hline $\mathrm{PD}$ & Physical Disability & $\begin{array}{l}=1 \text { if any member of household is physically disable } \\
=0 \text { if any member of household is not physically disable }\end{array}$ \\
\hline HEDU & $\begin{array}{l}\text { Education of the } \\
\text { Household Head }\end{array}$ & Total years of education \\
\hline
\end{tabular}

\subsection{Economic Development model}

Per capita income or economic development of the household is taken as a dependent variable.

They are provided in in functional form as below:

$$
L n P C I=f\left(\begin{array}{l}
H A G E, H S I Z E, H E D U, D R A T I O, O C C, N O E I H, \text { PHYASSETS }, O H, \\
R E M, \text { SPART }, C R E D I T, M E N T D, \text { PHYD }
\end{array}\right)
$$

The above model in econometric form as:

$$
\operatorname{LnPCI}=f\left(\begin{array}{l}
\beta_{0}+\beta_{1} H A G E+\beta_{2} H S I Z E+\beta_{3} H E D U+\beta_{4} D R A T I O+\beta_{5} O C C+\beta_{6} N O E I H \\
+\beta_{7} \text { PHYASSETS }+\beta_{8} O H+\beta_{9} R E M+\beta_{10} S P A R T+\beta_{11} C R E D I T \\
+\beta_{12} M E N T D+\beta_{13} P H Y D+\beta_{1}
\end{array}\right)
$$




\section{Empirical Findings}

This section begins by analyzing and examining the Economic Development of the households in Southern Punjab in the Table 4. An incline in age of respondent by one year will raise the economic development or per capita income by 0.8 percent. [Pfau and Giang (2009), Munyegera and Matsumoto (2016), Nguyen and Nguyen (2019)]. A rise in household size by one member will reduce the economic development or income per capita of the household by 8.3 percent [Leyaro and Morrissey (2010) and Tran et al., (2018)]. A rise in education of respondent by one year will raise their economic development or income per capita or by 5.1 percent. [Vedia-Jerez and Chasco (2016)]. As, if occupation of the respondent in primary sector rises by one unit, it will lead to reduce the income per capita or economic development by 28.6 percent [Shi et al. (2010), Urgessa (2015) and Tuyen (2015)]. An increase in dependent by one member in the household, it will lead to decrease the economic development or per capita earnings of the household by 15.3 percent [Shi et al., (2010) and Tuyen et al., (2014)]. A rise in mental disability of the household by one unit, it will reduce the income per capita of the household by 33.9 percent [Deaton (2003)]. A rise in mental disability of household by one unit, it will reduce the income per capita of the household by 29.1 percent [Deaton (2003)]. If holding an own house by the household increase by one unit, it will raise the or economic development or income per capita of the household by 38.6 percent, respectively [ Tuyen (2015)]. If the spouse's participation rises by one unit in the economic activities, it will lead to increase the per capita earnings of the household by 14.8 percent. [Torr (2011) and Goldscheider et al., (2015)].Moreover, if remittances increase by 1 unit, it will result an increase in the per capita earnings or economic development of the household by 17.6 percent [Pede et al., (2011), Alobo et al., (2017)]. Access to credit by the household increases to 1 unit, it will lead to increase the economic development or per capita earnings of the household by 4.2 percent. [Akotey and Adjasi (2016)]. A rise in earners in household by one member will result an increase in the economic development or per capita earnings by the household by 9.3 percent [ Vatta and Sidhu (2007) and Jehovaness (2010)]. If value of physical assets rises by one percent, it leads to rise the income per capita of the household by 2.1 percent [Abdelhak et al., (2012), Vedia-Jerez and Chasco (2016)].

Table 2: Descriptive Analysis of Economic Development in Southern Punjab.

\begin{tabular}{|l|l|l|}
\hline Variables & Mean & Standard Deviation \\
\hline Per Capita Income & 9864.69 & 7730.97 \\
\hline Mental Disability & 0.09 & 0.29 \\
\hline Value of Physical Assets & 4834496 & 11281889 \\
\hline Number Of Earners in the Household & 2.04 & 1.08 \\
\hline Occupation of the Household Head & 0.57 & 0.50 \\
\hline Own House & 0.90 & 0.30 \\
\hline Remittances & 0.12 & 0.32 \\
\hline Spouse's Participation & 0.16 & 0.37 \\
\hline Household Size & 6.34 & 2.55 \\
\hline Household Head Education & 8.29 & 5.56 \\
\hline Household Head Age & 48.18 & 12.76 \\
\hline Dependency Ratio & 0.75 & 0.73 \\
\hline Access to Credit & 0.12 & 0.33 \\
\hline Physical Disability & 0.11 & 0.31 \\
\hline
\end{tabular}

Source: Survey data, 2019 
Table 3: Correlation Analysis of Economic Development and its Correlates in Southern Punjab

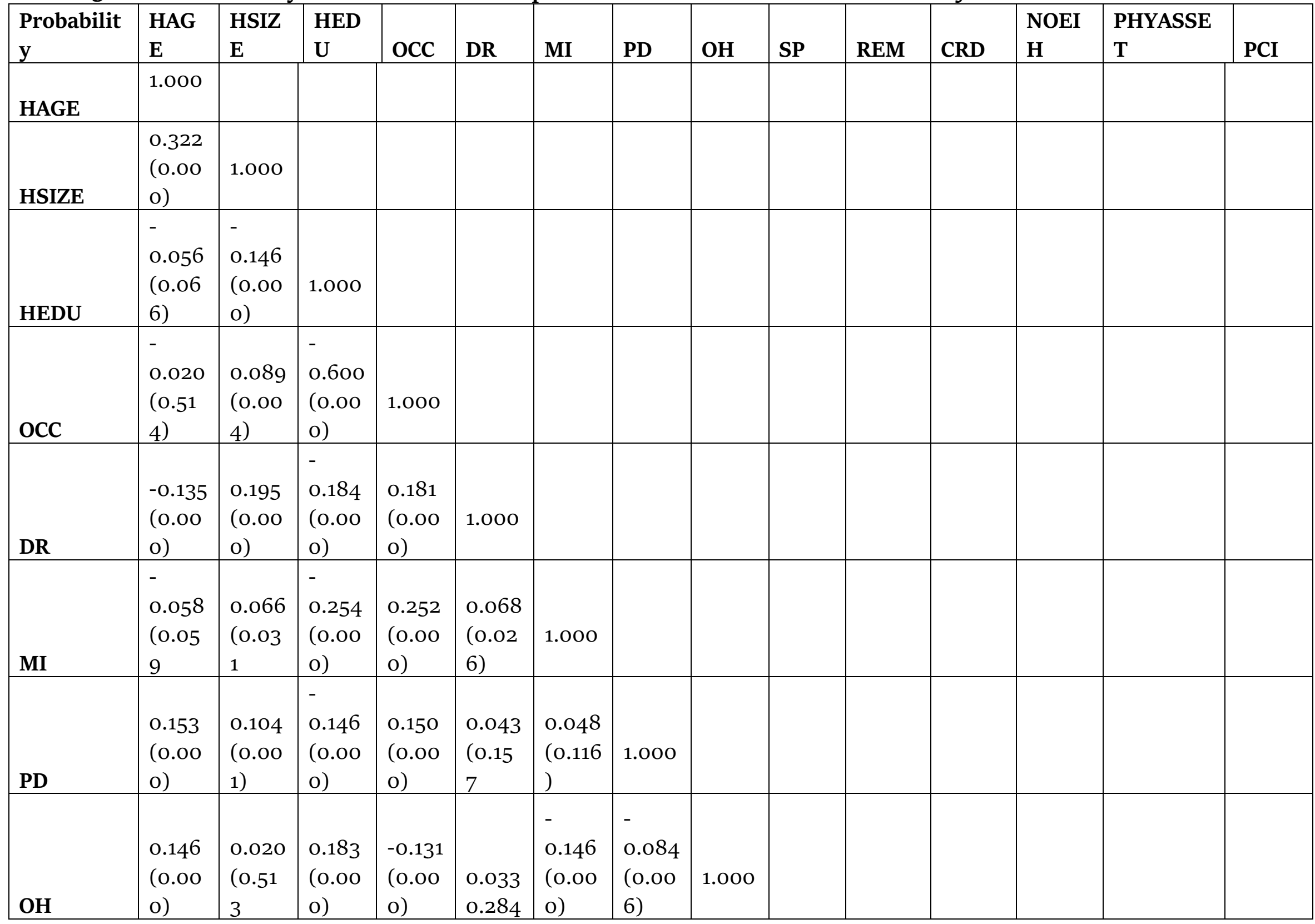




\begin{tabular}{|c|c|c|c|c|c|c|c|c|c|c|c|c|c|c|}
\hline SP & $\begin{array}{l}0.144 \\
(0.00 \\
0)\end{array}$ & $\begin{array}{l}0.085 \\
(0.00 \\
5)\end{array}$ & $\begin{array}{l}0.127 \\
(0.00 \\
0)\end{array}$ & $\begin{array}{l}- \\
0.146 \\
(0.00 \\
0)\end{array}$ & $\begin{array}{l}- \\
0.199 \\
(0.00 \\
0)\end{array}$ & $\begin{array}{l}- \\
0.060 \\
(0.04 \\
9\end{array}$ & $\begin{array}{l}- \\
0.009 \\
(0.76 \\
8\end{array}$ & $\begin{array}{l}0.081 \\
(0.00 \\
8)\end{array}$ & 1.000 & & & & & \\
\hline NOEIH & $\begin{array}{l}0.356 \\
(0.00 \\
0)\end{array}$ & $\begin{array}{l}0.469 \\
(0.00 \\
0)\end{array}$ & $\begin{array}{l}0.089 \\
(0.00 \\
\text { o) }\end{array}$ & $\begin{array}{l}- \\
0.090 \\
(0.00 \\
3)\end{array}$ & $\begin{array}{l}- \\
0.391 \\
(0.00 \\
\text { o) }\end{array}$ & $\begin{array}{l}- \\
0.095 \\
(0.00 \\
2)\end{array}$ & $\begin{array}{l}0.020 \\
(0.52 \\
3)\end{array}$ & $\begin{array}{l}0.144 \\
(0.00 \\
0)\end{array}$ & $\begin{array}{l}0.369 \\
(0.00 \\
0)\end{array}$ & $\begin{array}{l}0.227 \\
(0.00 \\
0)\end{array}$ & $\begin{array}{l}0.072 \\
(0.018 \\
)\end{array}$ & 1.000 & & \\
\hline PCI & $\begin{array}{l}0.091 \\
(0.00 \\
3)\end{array}$ & $\begin{array}{l}- \\
0.225 \\
(0.00 \\
0) \\
\end{array}$ & $\begin{array}{l}0.476 \\
(0.00 \\
0)\end{array}$ & $\begin{array}{l}- \\
0.412 \\
(0.00 \\
\text { o) }\end{array}$ & $\begin{array}{l}- \\
0.268 \\
(0.00 \\
0)\end{array}$ & $\begin{array}{l}- \\
0.250 \\
(0.00 \\
0)\end{array}$ & $\begin{array}{l}- \\
0.164 \\
(0.00 \\
\text { o) }\end{array}$ & $\begin{array}{l}0.212 \\
(0.00 \\
0)\end{array}$ & $\begin{array}{l}0.172 \\
(0.00 \\
0)\end{array}$ & $\begin{array}{l}0.180 \\
(0.00 \\
0)\end{array}$ & $\begin{array}{l}0.027 \\
(0.371 \\
)\end{array}$ & $\begin{array}{l}0.142 \\
(0.000 \\
)\end{array}$ & $\begin{array}{l}0.085 \\
(0.005)\end{array}$ & 1.000 \\
\hline
\end{tabular}

Source: Survey data, 2019 ; probability in brackets 
Table 4: Econometric Analysis of Factors Affecting Economic Development in Southern Punjab

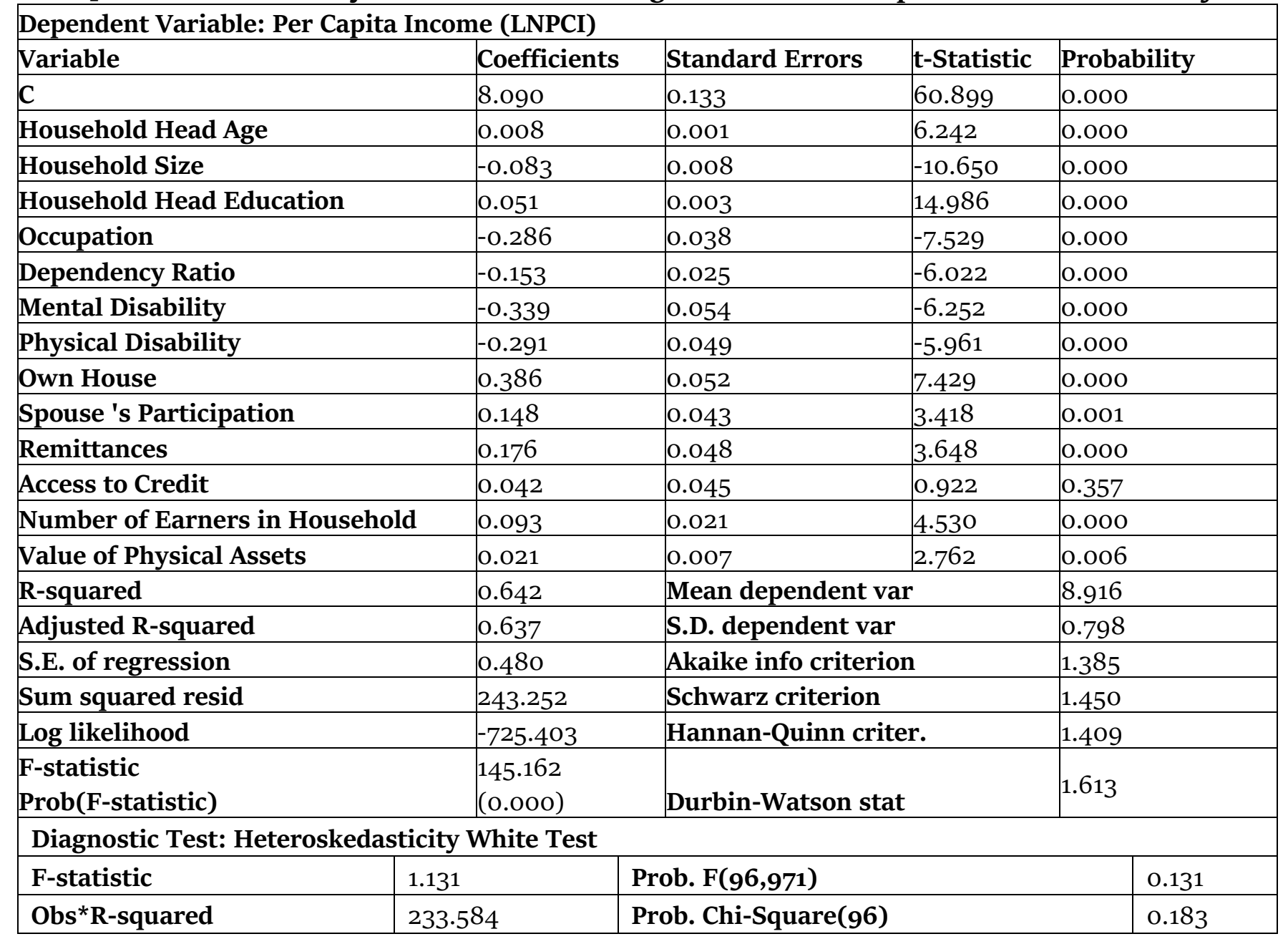

Source: Survey data, 2019

Table 5 presents the OLS regression results of econometric analysis of factors affecting economic development in Multan division. An increase in age of respondent by one year will raise the per capita income or economic development by o.9 percent [Nee (1996), Chang and Hanna (1994) and Brück (2001)]. Moreover, a rise in household size by one member, will reduce the per capita earnings of the household by 7.9 percent [Jansen et al., (2006), Baiyegunhi and Fraser (2010), Sekhampu, (2013), Tuyen et al., (2014), Jin and Xie (2017)]. If education of household head rises by one year, it leads to rise per capita income or economic development by 5.4 percent. [Estudillo et al., (2008), Jehovaness (2010), Pede et al., (2011) and Ackah (2013) in their studies. If occupation of respondent in primary sector rises by one unit, it will lead to reduce the economic development or income per capita or by 27.2 percent (Sumberg et al. 2004). An increase in dependent by one member in the household, it will lead to decrease the per capita income or economic development of the household by 14.8 percent [Brück, (2001), Akerele and Adewuyi (2011)]. An increase in mental disability of household by one unit, it will reduce the economic development or per capita earnings of the household by 37.1 percent. An increase in physical disability of the household by one unit, it will reduce the economic development or per capita earnings or of the household by 28.4 percent [Scott (2000), Mirvis and Clay (2008]. If holding an own house by the household increase by one unit, it will raise the economic development or income per capita of the household by 40.7 percent, respectively [(Glewwe, 1991)]. If the spouse's participation increases by one unit in the economic activities, it will lead to rise the economic development or income per capita of the household by 5.5 percent [Plutzer (1991), Bolzendahl and Myers (2004)]. As remittances received by the household increase by 1 unit, it will result a rise in the economic 
development or income per capita by 20.3 percent [Shahbaz et al., (2008), Le (2009) and Marwan et al. (2013)]. If access to credit by household increases to 1 unit, it will lead to increase the economic development or per capita earnings of the household by 0.9 percent. (Kessy and Urio, 2006; Cuong, 2008). If earners increase by one member in the household, it will lead an increase in the economic development or per capita earnings of the household by 10.6 percent. [Vatta and Sidhu (2007), Jehovaness, (2010)].

Table 5: Results of the Econometric Analysis of Factors Affecting Economic Development in Multan Division

\begin{tabular}{|c|c|c|c|c|}
\hline \multicolumn{5}{|c|}{ Dependent Variable: Per Capita Income (LNPCI) } \\
\hline Variable & Coefficients & Standard Errors & t-Statistic & Probability \\
\hline C & 7.995 & 0.237 & 33.761 & 0.000 \\
\hline Household Head's Age & 0.009 & 0.002 & 3.742 & 0.000 \\
\hline Household Size & -0.079 & 0.014 & -5.619 & 0.000 \\
\hline Household Head 'sEducation & 0.054 & 0.006 & 8.745 & 0.000 \\
\hline Occupation & -0.272 & 0.070 & -3.890 & 0.000 \\
\hline Dependency Ratio & -0.148 & 0.045 & -3.278 & 0.001 \\
\hline Mental Disability & -0.371 & 0.099 & -3.736 & 0.000 \\
\hline Physical Disability & -0.284 & 0.090 & -3.148 & 0.002 \\
\hline Own House & 0.407 & 0.096 & 4.250 & 0.000 \\
\hline Spouse 's Participation & 0.055 & 0.075 & 0.740 & 0.460 \\
\hline Remittances & 0.203 & 0.087 & 2.333 & 0.020 \\
\hline Access to Credit & 0.009 & 0.082 & 0.114 & 0.909 \\
\hline Number of Earners in Household & 0.106 & 0.038 & 2.772 & 0.006 \\
\hline Value of Physical Assets & 0.023 & 0.012 & 1.825 & 0.069 \\
\hline R-squared & 0.617 & \multicolumn{2}{|c|}{ Mean dependent var } & 8.960 \\
\hline Adjusted R-squared & 0.603 & \multicolumn{2}{|c|}{ S.D. dependent var } & 0.824 \\
\hline S.E. of regression & 0.519 & \multicolumn{2}{|c|}{ Akaike info criterion } & 1.563 \\
\hline Sum squared resid & 97.863 & \multicolumn{2}{|l|}{ Schwarz criterion } & 1.710 \\
\hline Log likelihood & -280.715 & \multicolumn{2}{|c|}{ Hannan-Quinn criter. } & 1.621 \\
\hline $\begin{array}{l}\text { F-statistic } \\
\text { Prob(F-statistic) }\end{array}$ & $\begin{array}{l}44.897 \\
(0.000)\end{array}$ & \multicolumn{2}{|c|}{ Durbin-Watson stat } & 1.567 \\
\hline \multicolumn{5}{|c|}{ Diagnostic Test: Heteroskedasticity White Test } \\
\hline F-statistic & 1.163 & \multicolumn{2}{|l|}{ Prob. F(95,281) } & 0.118 \\
\hline Obs*R-squared & 140.788 & \multicolumn{2}{|c|}{ Prob. Chi-Square(95) } & 0.122 \\
\hline
\end{tabular}

Source: Survey data, 2019

Table 6 presents the OLS regression results of the factors affecting economic development in Bahawalpur division. With a rise in the age of respondent by one year will raise the per capita income or economic development by 0.7 percent [Smith (2007) Tuyen (2014a). An increase in household size by one member, will reduce the economic development or earnings per capita of the household by $7 \cdot 5$ percent [Biyase and Zwane (2018)]. A rise in education of the respondent by one year will raise their income per capita by 4.6 percent [Yúnez-Naude and Taylor (2001) and Croppenstedt (2006)]. Moreover, the occupation of respondent in primary sector rise by one unit, it will lead to reduce the income per capita of the household by 29.5 percent. Same results are concluded by Abdulai and CroleRees (2001). A rise in dependent by one member in the household, it will lead to decrease the per capita earnings of the household by 19.5 percent [ Akerele and Adewuyi (2011), Lekobane and Seleka (2017)]. An increase in mental disability of the household by one unit, it will reduce the income per 
capita of the household by 33.4 percent. (Joffe-Walt, 2013). An incline in physical disability of the household by one unit, it will reduce the economic development or per capita earnings or of the household by 28.9 percent. (Lakdawalla et al., 2004). If holding an own house increase by one unit, it will raise the economic development or per capita earnings of the household by 35.5 percent. If the spouse's participation increases by one unit in economic activities, it will lead to increase the economic development or per capita earnings of the household by 24 percent [Nock (2001)and Jalovaara (2012)]. If the remittances received by the household increase by 1 unit, it will result an increase in the economic development or earnings per capita of the household by 12.2 percent [Adams (2006) and Quartey (2006). If access to credit by household increases to 1 unit, it will lead to rise the economic development or per capita earnings of the household by 11.3 percent [Imai and Azam (2012), Khandker and Samad (2013)]. The income per capita of the household increase by 0.053 percent with an increase in one more person start earnings in the household. An increase in earners in the household by one member will result a rise in the per capita earnings of the household by 5.4 percent. [Vatta and Sidhu (2007)]. As the value of physical assets increase by one percent, it leads to raise the income per capita of the household by 3.3 percent [Webb et al., (1992) and Bebbington (1999)].

Table 6: Results of the Econometric Analysis of Factors Affecting Economic Development in Bahawalpur Division

\begin{tabular}{|c|c|c|c|c|}
\hline \multicolumn{5}{|c|}{ Dependent Variable: Per Capita Income (LNPCI) } \\
\hline \multicolumn{2}{|r|}{ Coefficients } & Standard Errors & t-Statistic & Probability \\
\hline C & 8.092 & 0.227 & 35.602 & 0.000 \\
\hline Household Head Age & 0.007 & 0.002 & 3.343 & 0.001 \\
\hline Household Size & -0.075 & 0.013 & -5.704 & 0.000 \\
\hline Household Head Education & 0.046 & 0.006 & 7.865 & 0.000 \\
\hline Occupation & -0.295 & 0.066 & -4.473 & 0.000 \\
\hline Dependency Ratio & -0.195 & 0.044 & -4.457 & 0.000 \\
\hline Mental Disability & -0.334 & 0.091 & -3.650 & 0.000 \\
\hline Physical Disability & -0.289 & 0.082 & -3.543 & 0.001 \\
\hline Own House & 0.355 & 0.088 & 4.057 & 0.000 \\
\hline Spouse 's Participation & 0.240 & 0.077 & 3.133 & 0.002 \\
\hline Remittances & 0.122 & 0.078 & 1.577 & 0.116 \\
\hline Access to Credit & 0.113 & 0.108 & 1.049 & 0.295 \\
\hline Number of Earners in Household & 0.054 & 0.035 & 1.522 & 0.129 \\
\hline Value of Physical Assets & 0.033 & 0.014 & 2.345 & 0.020 \\
\hline R-squared & 0.664 & \multicolumn{2}{|c|}{ Mean dependent var } & 8.915 \\
\hline Adjusted R-squared & 0.651 & S.D. dependent $\mathrm{v}$ & & 0.789 \\
\hline S.E. of regression & 0.466 & Akaike info crite & & 1.350 \\
\hline Sum squared resid & 73.648 & Schwarz criterior & & 1.503 \\
\hline Log likelihood & -224.281 & Hannan-Quinn cı & & 1.411 \\
\hline $\begin{array}{l}\text { F-statistic } \\
\text { Prob(F-statistic) }\end{array}$ & $\begin{array}{l}51.460 \\
\text { (o.00o) }\end{array}$ & Durbin-Watson s & & 1.672 \\
\hline Diagnostic Test: Heteroskedasti & ty White Test & & & \\
\hline F-statistic & 1.325 & Prob. F(95,257) & & 0.122 \\
\hline Obs*R-squared & 132.454 & Prob. Chi-Square( & & 0.128 \\
\hline
\end{tabular}

Source: Survey data, 2019

The Table 7 presents the factors affecting economic development in D.G. Khan Division. A rise in age of respondent by one year will raise the per capita income or economic development by 0.8 percent. [Nguyen and Nguyen (2019)]. With an inclined in household size by one member, will reduce the per 
capita earnings of the household by 10 percent [Biyase and Zwane (2018), Nguyen and Nguyen, 2019)]. A rise in education of household head by one year will raise their income per capita by 5.6 percent [Ali et al., (2012), Su and Heshmati (2013)]. If occupation of respondent in primary sector increase by one unit, it will lead to reduce the per capita income by 27.3 percent [Rigg, 2006; Tuyen, 2014b)]. An increase in dependent by one member in the household, it will lead to decrease the income per capita of the household by 11 percent [Scott (2000), Nguyen and Nguyen (2019)]. An increase in mental disability of household by one unit, it will reduce the income per capita of the household by 31.7 percent [Smith (1999)]. A rise in mental disability of household by one unit, it will reduce the income per capita of the household by 31.7 percent (Case and Deaton 2003). If holding an own house by the household increase by one unit, it will raise the income per capita of the household by 38.3 percent, respectively. [Smith (2007)]. If the spouse participates in the economic activity rises by one unit, it will lead to increase the income per capita of the household by 10.5 percent [Torr (2011)]. As, the remittances received by household increase by 1 unit, it leads to rise the income per capita of the household by 19.7 percent [Dey (2015) and Hossain (2015)]. If the access to credit by the household increases to 1 unit, it will lead to increase the per capita income or economic development of the household by $7 \cdot 3$ percent [(Khandker and Samad, 2013)]. A rise in earners in household by one member leads to rise in the income per capita of the household by 13.3 percent [(Vatta and Sidhu (2007)]. If the value of physical assets possessed by the household increase by one percent, it leads to rise the income per capita of the household by 1.4 percent [Scott (2000), Van de Walle and Cratty (2004)].

Table 7: Results of the Econometric Analysis of Factors Affecting Economic Development in D.G. Khan Division

\begin{tabular}{|c|c|c|c|c|}
\hline \multicolumn{5}{|c|}{ Dependent Variable: Per Capita Income (LNPCI) } \\
\hline Variable & Coefficients & Standard Errors & t-Statistic & Probability \\
\hline C & 8.050 & 0.241 & $33 \cdot 390$ & 0.000 \\
\hline Household Head Age & 0.008 & 0.002 & 3.819 & 0.000 \\
\hline Household Size & -0.100 & 0.013 & -7.430 & 0.000 \\
\hline Household Head Education & 0.056 & 0.006 & 9.505 & 0.000 \\
\hline Occupation & -0.273 & 0.062 & -4.400 & 0.000 \\
\hline Dependency Ratio & -0.110 & 0.043 & -2.552 & 0.011 \\
\hline Mental Disability & -0.317 & 0.092 & -3.460 & 0.001 \\
\hline Physical Disability & -0.330 & 0.084 & -3.950 & 0.000 \\
\hline Own House & 0.383 & 0.089 & 4.318 & 0.000 \\
\hline Spouse 's Participation & 0.105 & 0.082 & 1.271 & 0.205 \\
\hline Remittances & 0.197 & 0.089 & 2.209 & 0.028 \\
\hline Access to Credit & 0.073 & 0.065 & 1.113 & 0.266 \\
\hline Number of earners in Household & 0.133 & 0.034 & 3.861 & 0.000 \\
\hline Value of Physical Assets & 0.014 & 0.014 & 0.990 & 0.323 \\
\hline R-squared & 0.673 & Mean dependent & & 8.868 \\
\hline Adjusted R-squared & 0.660 & S.D. dependent v & & 0.776 \\
\hline S.E. of regression & 0.452 & Akaike info crite & & 1.292 \\
\hline Sum squared resid & 66.338 & Schwarz criterio & & 1.451 \\
\hline Log likelihood & -204.420 & Hannan-Quinn c & er. & 1.356 \\
\hline $\begin{array}{l}\text { F-statistic } \\
\text { Prob(F-statistic) }\end{array}$ & $\begin{array}{l}51.362 \\
(0.000)\end{array}$ & Durbin-Watson s & & 1.739 \\
\hline \multicolumn{5}{|c|}{ Diagnostic Test: Heteroskedasticity White Test } \\
\hline \multicolumn{2}{|c|}{\begin{tabular}{l|l} 
F-statistic & 1.246 \\
\end{tabular}} & \multicolumn{2}{|l|}{ Prob. $F(96,241)$} & 0.192 \\
\hline Obs*R-squared & 112.121 & \multicolumn{2}{|c|}{ Prob. Chi-Square(96) } & 0.225 \\
\hline
\end{tabular}

Source: Survey data, 2019 
Table 8 presents the comparative analysis of the econometric results of the factors affecting poverty in Southern Punjab and its division,

Table 8: Comparative Analysis of Factors Affecting Economic Development in Southern Punjab and Its Division.

\begin{tabular}{|c|c|c|c|c|}
\hline \multicolumn{5}{|c|}{ Dependent Variable: Per Capita Income (LNPCI) } \\
\hline Variable & $\begin{array}{l}\text { Coefficients } \\
\text { Multan Division }\end{array}$ & $\begin{array}{l}\text { Coefficients } \\
\text { Bahawalpur } \\
\text { Division } \\
\end{array}$ & $\begin{array}{l}\text { Coefficients } \\
\text { D.G. Khan } \\
\text { Division }\end{array}$ & $\begin{array}{l}\text { Coefficients } \\
\text { Southern } \\
\text { Punjab }\end{array}$ \\
\hline C & $\begin{array}{l}7.995 \\
(0.237) \\
\end{array}$ & $\begin{array}{l}8.092 \\
(0.227)\end{array}$ & $\begin{array}{l}8.050 \\
(0.241)\end{array}$ & $\begin{array}{l}8.090 \\
(0.133)\end{array}$ \\
\hline Household Head Age & $\begin{array}{l}0.009 \\
(0.002)\end{array}$ & $\begin{array}{l}0.007 \\
(0.002)\end{array}$ & $\begin{array}{l}0.008 \\
(0.002)\end{array}$ & $\begin{array}{l}0.008 \\
(0.001)\end{array}$ \\
\hline Household Size & $\begin{array}{l}-0.079 \\
(0.014) \\
\end{array}$ & $\begin{array}{l}-0.075 \\
(0.013) \\
\end{array}$ & $\begin{array}{l}-0.100 \\
(0.013) \\
\end{array}$ & $\begin{array}{l}-0.083 \\
(0.008)\end{array}$ \\
\hline Household Head Education & $\begin{array}{l}0.054 \\
(0.006)\end{array}$ & $\begin{array}{l}0.046 \\
(0.006)\end{array}$ & $\begin{array}{l}0.056 \\
(0.006)\end{array}$ & $\begin{array}{l}0.051 \\
(0.003)\end{array}$ \\
\hline Occupation & $\begin{array}{l}-0.272 \\
(0.070)\end{array}$ & $\begin{array}{l}-0.295 \\
(0.066)\end{array}$ & $\begin{array}{l}-0.273 \\
(0.062)\end{array}$ & $\begin{array}{l}-0.286 \\
(0.038)\end{array}$ \\
\hline Dependency Ratio & $\begin{array}{l}-0.148 \\
(0.045)\end{array}$ & $\begin{array}{l}-0.195 \\
(0.044)\end{array}$ & $\begin{array}{l}-0.110 \\
(0.043)\end{array}$ & $\begin{array}{l}-0.153 \\
(0.025)\end{array}$ \\
\hline Mental Disability & $\begin{array}{l}-0.371 \\
(0.099)\end{array}$ & $\begin{array}{l}-0.334 \\
(0.091) \\
\end{array}$ & $\begin{array}{l}-0.317 \\
(0.092)\end{array}$ & $\begin{array}{l}-0.339 \\
(0.054)\end{array}$ \\
\hline Physical Disability & $\begin{array}{l}-0.284 \\
(0.090)\end{array}$ & $\begin{array}{l}-0.289 \\
(0.082)\end{array}$ & $\begin{array}{l}-0.330 \\
(0.084)\end{array}$ & $\begin{array}{l}-0.291 \\
(0.049)\end{array}$ \\
\hline Own House & $\begin{array}{l}0.407 \\
(0.096) \\
\end{array}$ & \begin{tabular}{|l}
0.355 \\
$(0.088)$
\end{tabular} & $\begin{array}{l}0.383 \\
(0.089)\end{array}$ & $\begin{array}{l}0.386 \\
(0.052)\end{array}$ \\
\hline Spouse 's Participation & $\begin{array}{l}0.055 \\
(0.075)\end{array}$ & $\begin{array}{l}0.240 \\
(0.077)\end{array}$ & \begin{tabular}{|l}
0.105 \\
$(0.082)$
\end{tabular} & $\begin{array}{l}0.148 \\
(0.043) \\
\end{array}$ \\
\hline Remittances & $\begin{array}{l}0.203 \\
(0.087)\end{array}$ & $\begin{array}{l}0.122 \\
(0.078)\end{array}$ & $\begin{array}{l}0.197 \\
(0.089)\end{array}$ & $\begin{array}{l}0.176 \\
(0.048)\end{array}$ \\
\hline Access to Credit & $\begin{array}{l}0.009 \\
(0.082)\end{array}$ & $\begin{array}{l}0.113 \\
(0.108)\end{array}$ & $\begin{array}{l}0.073 \\
(0.065)\end{array}$ & $\begin{array}{l}0.042 \\
(0.045)\end{array}$ \\
\hline Number of Earners in Household & $\begin{array}{l}0.106 \\
(0.038) \\
\end{array}$ & $\begin{array}{l}0.054 \\
(0.035)\end{array}$ & \begin{tabular}{|l}
0.133 \\
$(0.034)$
\end{tabular} & $\begin{array}{l}0.093 \\
(0.021) \\
\end{array}$ \\
\hline Value of Physical Assets & $\begin{array}{l}0.023 \\
(0.012) \\
\end{array}$ & \begin{tabular}{|l}
0.033 \\
$(0.014)$
\end{tabular} & \begin{tabular}{|l}
0.014 \\
$(0.014)$
\end{tabular} & $\begin{array}{l}0.021 \\
(0.007)\end{array}$ \\
\hline R-squared & 0.617 & 0.664 & 0.673 & 0.642 \\
\hline Adjusted R-squared & 0.603 & 0.651 & 0.660 & 0.637 \\
\hline S.E. of regression & 0.519 & 0.466 & 0.452 & 0.480 \\
\hline Sum squared resid & 97.863 & 73.648 & 66.338 & 243.252 \\
\hline Log likelihood & -280.715 & -224.281 & -204.420 & -725.403 \\
\hline F-statistic & 44.897 & 51.460 & 51.362 & 145.162 \\
\hline
\end{tabular}

Source: Survey data, 2019; Standard errors in brackets.

\section{Concluding Remarks}

This paper explains the socio-economic status and factors affecting Economic Development in Southern Punjab, consisting of three divisions which are Multan, Bahawalpur and D.G. Khan Division. The study consisting of 1068 observations, OLS regression has been employed for empirical analysis. 
The study concludes that the house hold size, occupation in informal sector, dependency ratio, physical disability and mental disability shows a negative correlation with per capita earnings. The household head education, age, remittances, spouse's participation, number of earners in the household, access to credit, own house possession and physical assets shows a direct correlation with per capita earnings of the respondents in Southern Punjab.

The analysis discussed above assist the policy makers to clearly identify the factors for Economic Development in Southern Punjab. It is also drawn from the conclusion that large household size and dependency ratio generates low per capita income and hinders the development of the country. Government should invest on the development of the infrastructure of the rural and remote areas. Initiate new development projects for schools, colleges, universities, hospitals, roads, electricity, internet and transport facilities are necessary for the people living in rural areas.

\section{References}

Abdelhak, S., Sulaiman, J., \& Mohd, S. (2012). The Role of Assets in The Enhancement of Households' Income: A Study of Poverty Alleviation Among Rural Communities of Kelantan and Terengganu. Asian Social Science, 8(11), 145.

Abdulai, A., \& Crolerees, A. (2001). Determinants of Income Diversification Amongst Rural Households in Southern Mali. Food Policy, 26(4), 437-452.

Ackah, C. (2013). Nonfarm Employment and Incomes in Rural Ghana. Journal of International Development, 25(3), 325-339.

Adams R. H. Jr. (2006). Remittances and Poverty in Ghana. World Bank Policy Research Paper 3838. Washington, DC.

Aikaeli, J. (2011). Determinants of Rural Income in Tanzania: An Empirical Approach. Tanzanian Economic Review, 1(1-2), 99-115.

Akerele, D., \& Adewuyi, S. A. (2011). Analysis of Poverty Profiles and Socioeconomic Determinants of Welfare Among Urban Households of Ekiti State, Nigeria. Current Research Journal of Social Sciences, 3(1), 1-7.

Akotey, J. O., \& Adjasi, C. K. (2016). Does Microcredit Increase Household Welfare in The Absence of Micro insurance? World Development, 77, 380-394.

Ali, S., Chaudhry, I, S., \& Farooq, F. (2012). Human Capital Formation and Economic Growth in Pakistan. Pakistan Journal of Social Sciences, 32, (1), 229-240.

Alobo Loison, S., \& Bignebat, C. (2017). Patterns and Determinants of Household Income Diversification in Rural Senegal and Kenya. Journal of Poverty Alleviation \& International Development, 8(1).

Baiyegunhi, L. J. S., \& Fraser, G. C. (2010). Determinants of Household Poverty Dynamics in Rural Regions of the Eastern Cape Province, South Africa (No. 308-2016-5070).

Barro, R. J., \& Lee, J. W. (1994, June). Sources of Economic Growth. In Carnegie-Rochester Conference Series On Public Policy (Vol. 40, Pp. 1-46). North-Holland.

Bebbington, A. (1999). Capitals and Capabilities: A Framework for Analyzing Peasant Viability, Rural Livelihoods and Poverty. World Development, 27(12), 2021-2044.

Biyase, M., \& Zwane, T. (2018). An Empirical Analysis of the Determinants of Poverty and Household Welfare in South Africa. The Journal of Developing Areas, 52(1), 115-130.

Bolzendahl, C. I. And Myers, D. J.; 2004; 'Feminist Attitudes and Support for Gender Equality: Opinion Change in Women and Men, 1974-1998'. Social Forces. 83, 759-790.

Brück, T. (2001). Determinants of Rural Poverty in Post-War Mozambique: Evidence from A Household Survey and Implications for Government and Donor Policy. Queen Elizabeth House, University of Oxford.

Chang, Y. R., \& Hanna, S. (1994). Determinants of Household Expected Real Income Growth in The 
USA. Journal of Consumer Studies \& Home Economics, 18(4), 315-329.

Cuong, N. V. (2008). Is A Governmental Micro-Credit Program for The Poor Really Pro-Poor? Evidence from Vietnam. The Developing Economies, 46(2), 151-187.

Croppenstedt, A. (2006). Household Income Structure and Determinants in Rural Egypt (No. 289065).

Food and Agriculture Organization of the United Nations, Agricultural Development Economics Division (ESA).

Deaton, A. (2003). Health, Income, And Inequality. National Bureau of Economic Research Reporter: Research Summary. Retrieved August, 15, 2009.

Dey, S. (2015). Impact of Remittances On Poverty at Origin: A Study On Rural Households in India Using Covariate Balancing Propensity Score Matching. Migration and Development, 4(2), 185199.

Estudillo, J. P., Sawada, Y., \& Otsuka, K. (2008). Poverty and Income Dynamics in Philippine Villages, 1985-2004. Review of Development Economics, 12(4), 877-890.

Glewwe, P. (1991). Investigating The Determinants of Household Welfare in Côte d'Ivoire. Journal of Development Economics, 35(2), 307-337.

Goldscheider, F. K., Bernhardt, E., \& Lappegård, T. (2015). The Gender Revolution: A Framework for Understanding Changing Family and Demographic Behavior. Population and Development Review,41(2), 207-239.

Hall, R.E. \&Jones, C.I. (1999). Why Do Some Countries Produce So Much More Output Per Worker Than Others? Quarterly Journal of Economics, 114(1), 83-116.

Imai, K. S., \& Azam, M. S. (2012). Does Microfinance Reduce Poverty in Bangladesh? New Evidence from Household Panel Data. Journal of Development Studies, 48(5), 633-653.

Jalovaara, M. (2012). Socio-Economic Resources and First-Union Formation in Finland, Cohorts Born 1969-81. Population Studies,66(1), 69-85.

Jansen, H. G., Pender, J. L., Damon, A. L., \& Schipper, R. A. (2006). Land Management Decisions and Agricultural Productivity in The Hillsides of Honduras (No. 1004-2016-78474).

Jehovaness, A. (2010). Determinants of Rural Income in Tanzania: An Empirical Approach. Research Approach, 10(4).

Jin, Y., \& Xie, Y. (2017). Social Determinants of Household Wealth and Income in Urban China. Chinese Journal of Sociology, 3(2), 169-192.

Joffe-Walt, C. (2013). Kids Stay On Disability. National Public Radio.

Khandker, S. R., Samad, H. A., \& Ali, R. (2013). Does access to finance matter in microenterprise growth? Evidence from Bangladesh. The World Bank.

Lakdawalla, D. N., Bhattacharya, J., \& Goldman, D. P. (2004). Are The Young Becoming More Disabled? Health Affairs, 23(1), 168-176.

Kessy, S. A., \& Urio, F. M. (2006). Contribution of Microfinance Institutions to Poverty Reduction in Tanzania. Sumber: Http://Www. Repoa. Or. Tz/Documents Storage/Publications. Reports/o6 Kessy and Urio.

Le, T. (2009). Trade, Remittances, Institutions, And Economic Growth. International Economic Journal, 23 (3):391-408.

Lekobane, K. R., \& Seleka, T. B. (2017). Determinants of Household Welfare and Poverty in Botswana, 2002/2003 And 2009/2010. Journal of Poverty, 21(1), 42-60.

Leyaro, V., \& Morrissey, O. (2010). Protection and The Determinants of Household Income in Tanzania 1991-2007 (No. 10/03). CREDIT Research Paper

Lucas R. (1988). On The Mechanics of Economic Development. Journal of Monetary Economics, 22, 342.

Marwan, N. F., N. A. A. Kadir, A. Hussin, A. A. Zaini, M. E. Ab Rashid, And Z. A. G. Helmi. (2013). Export, Aid, Remittance and Growth: Evidence from Sudan. Procedia Economics and Finance, 
7:3-10.

Mirvis, D. M., \& Clay, J. A. (2008). Health and Economic Development: Reframing The Pathway. Journal of Health and Human Services Administration, 134-155.

Munyegera, G. K., \& Matsumoto, T. (2016). Mobile Money, Remittances, And Household Welfare: Panel Evidence from Rural Uganda. World Development, 79, 127-137.

Nock, S. L. (2001). The Marriages of Equally Dependent Spouses. Journal of Family Issues,22(6), 755775 .

Nguyen, H. M., \& Nguyen, T. A. (2019). Investigating The Determinants of Household Welfare in The Central Highland, Vietnam. Cogent Economics \& Finance, 7(1), 1684179

Pede, V. O., Luis, J. S., Paris, T. R., \& Mckinley, J. D. (2011). Determinants of Household Income: A Quantile Regression Approach for Four Rice-Producing Areas in The Philippines. Asian Journal of Agriculture and Development, 9(1362-2016-107601), 65-76.

Pfau, W. D., \& Giang, L. T. (2009). Determinants and Impacts of International Remittances On Household Welfare in Vietnam. International Social Science Journal, 6o(197-198), 431-443.

Plutzer, E. (1988). Work Life, Family Life, And Women's Support of Feminism. American Sociological Review, 640-649.

Quartey, P. (2006). The Impact of Migrant Remittances On Household Welfare in Ghana (No. RP_158). African Economic Research Consortium.

Rigg, J. (2006). Land, Farming, Livelihoods, And Poverty: Rethinking The Links in The Rural South. World Development, 34(1), 180-202.

Rodrik, D. (1999). Where Did All the Growth Go? Journal of Economic Growth, 4(4), 385-412.

Romer P. (1986). Increasing Returns and Long Run Growth. Journal of Political Economy, 94(2), 10021037.

Scott, C. D. (2000). Mixed Fortunes: A Study of Poverty Mobility Among Small Farm Households in Chile, 1968-86. The Journal of Development Studies, 36(6), 155-180.

Sekhampu, T, J. (2013). Determinants of Poverty in A South African Township. Journal of Social Science, 34(2), 145-153.

Shahbaz, M., Ahmad, K., \& Chaudhary, A. R. (2008). Economic Growth and Its Determinants in Pakistan. The Pakistan Development Review, 47(4-II), Pp-471.

Shi, X., Liu, X., Nuetah, A., \& Xin, X. (2010). Determinants of Household Income Mobility in Rural China. China \& World Economy, 18(2), 41-59.

Smith, J. P. (1999). Healthy Bodies and Thick Wallets: The Dual Relation Between Health and Economic Status. Journal of Economic Perspectives, 13(2), 145-166.

Smith, K. (2007). Determinants of Soviet Household Income. European Journal of Comparative Economics, 4(1).

Su, B., \& Heshmati, A. (2013). Analysis of The Determinants of Income and Income Gap Between Urban and Rural China. China Economic Policy Review, 2(01), 1350002.

Sumberg, J., Gilbert, E., \& Blackie, M. (2004). Income Diversity, Technology Choice and Agricultural Research Policy in Sub-Saharan Africa. Development Policy Review, 22(2), 131-146.

Torr, B. M. (2011). The Changing Relationship Between Education and Marriage in The United States, 1940-200o. Journal of Family History,36(4), 483-503.

Tran, T. A., Tran, T. Q., \& Nguyen, H. T. (2020). The Role of Education in The Livelihood of Households in The Northwest Region, Vietnam. Educational Research for Policy and Practice, 19(1), 63-88.

Tuyen, T. Q., Lim, S., Cameron, M. P., \& Huong, V. V. (2014). Farmland loss and livelihood outcomes: A Micro Econometric Analysis of Household Surveys in Vietnam. Journal of the Asia Pacific Economy, 19(3), 423-444.

Tuyen, T. Q. (2015). Socio-Economic Determinants of Household Income Among Ethnic Minorities in The North-West Mountains, Vietnam. Croatian Economic Survey, 17(1), 139-159. 
Urgessa, T. (2015). The Determinants of Agricultural Productivity and Rural Household Income in Ethiopia. Ethiopian Journal of Economics, 24(2), 63-91.

Van De Walle, D., \& Cratty, D. (2004). Is The Emerging Non-Farm Market Economy the Route Out of Poverty in Vietnam? Economics of Transition, 12(2), 237-274.

Vatta, K., \& Sidhu, R. S. (2007). Income Diversification Among Rural Households in Punjab: Dynamics, Impacts and Policy Implications. Indian Journal of Labour Economics, 50(4), 723-36.

Vedia-Jerez, D. H., \& Chasco, C. (2016). Long-Run Determinants of Economic Growth in South America. Journal of Applied Economics, 19(1), 169-192.

Webb, P., \& Reardon, T. (1992). Drought Impact and Household Response in East and West Africa. Quarterly Journal of International Agriculture, 31, 230-230.

Yúnez-Naude, A., \& Taylor, J. E. (2001). The Determinants of Nonfarm Activities and Incomes of Rural Households in Mexico, With Emphasis On Education. World Development, 29(3), 561-572 